\title{
IDEAS FOR TESTING OF PLANETARY GEAR SETS OF AUTOMOTIVE TRANSMISSIONS
}

\section{GABRIELA ACHTENOVÁ}

Czech Technical University in Prague, Faculty of Mechanical Engineering, Technická 4, Prague 6, gabriela.achtenova@fs.cvut.cz

\section{ABSTRACT}

The article describes the concept of modular stand, where is possible to provide tests of gear pairs with fixed axes from mechanical automotive gearboxes, as well as tests of separate planetary sets from automatic gearboxes. Special attention in the article will be paid to the variant dedicated for testing of planetary gear sets. This variant is particularly interesting because:

1) it is rarely described in the literature, and

2) this topology allows big simplification with respect to testing of standard gearwheels.

In the planetary closed-loop stand it is possible to directly link two identical planetary sets. Without any bracing flange or other connecting clutches, shafts or gear sets, just two planetary sets face-to-face will be assembled and connected to the electric motor.

KEYWORDS: CLOSED-LOOP TEST STAND, EFFICIENCY OF PLANETARY SET, ENDURANCE TESTS

\section{SHRNUTÍ}

Článek popisuje koncept modulárního zkušebního stanoviště, kde je možné testovat jak ozubené převody s pevnou osou, tak planetová soukolí. Zvláštní pozornost bude v článku věnována právě zkoušení planetových převodů. Tato varianta je zajímavá z několika důvodů: 1) je velmi málo popsána v literatuře,

2) uspořádání umožňuje velké zjednodušení v porovnání se stavem pro soukolí s pevnou osou.

V zkušebním stavu planetových soukolí je možné naprímo spojit dvě identická soukolí. Bez jakých koli prídavných spojek, hřídelů, nebo dalších převodů. Máme pouze dvě propojená soukolí, které jsou prímo poháněny elektromotorem.

KLIICOVÁ SLOVA: UZAVŘENÝ ZKUŠEBNÍ STAV, ÚČINNOST PLANETOVÝCH PŘEVODÚ, ŽIVOTNOSTNÍ ZKOUŠKY

\section{INTRODUCTION}

The physical testing of gearboxes, despite the quick development of simulation methods, remains a very important part of the design process. The main target is to determine the functional properties like efficiency, noise, vibrations, and endurance. The paper will be focused on closed-loop test stand. Big advantage of the closed-loop test stand is the possibility to build a cheap experimental device, which allows large range of experiments. Apart from endurance tests (typical for such device thanks to low energy demands) it will also be possible to measure transmission error, non-uniform load distribution on planets, vibrations and other parameters.

The idea to test gear wheels or whole gearboxes in a closed loop stand is generally attributed to Prof. Niemann [1]. The load is raised by elasticity forces when distorting the shafts with help of bracing flange and torque arm with weights. The load circulates in the whole test stand. The power from the motor is used only to compensate the losses in the stand.
Two identical gearwheels (gearboxes) are necessary. One is called tested gearbox, the other technological gearbox. The technological gearbox rotates the opposite sense of rotation. The load torque enters the technological gearbox via the output shaft. The opposite sense of rotation combined with opposite torque flow implies that in both gearboxes the same teeth flanks are loaded. For the gearwheels we can obtain two results from one endurance test. The technological gearbox is loaded with a torque diminished by efficiency of the previous parts of test stand.

As mentioned in previous paragraph the idea of the closedloop testing is well-known for many years, and is widely used. Universities [2], [3] and research companies dealing with research and development of gearwheels are equipped with such test stands. They are using in-house stands, or standard test machine manufactured by e.g. StramaMPS Maschinenbau GmbH [4]. The disadvantage is that most of the stands are dedicated for 
spur gears only; the gearwheel axis distance is approximatively $90 \mathrm{~mm}$, which is too much for automotive gearbox.

The mechanism of closed-loop test stand can be simplified if planetary gearsets will be used. Prof. Šalamoun [5] introduced the idea of usage of closed loop test stand for testing of planetary gearboxes. The test stand was newly built in laboratories of Czech Technical University in Prague. The concept, design and first results are presented in this paper.

\section{CLOSED LOOP STAND FOR PLANETARY}

\section{GEAR SETS}

There is a huge variety of composition of planetary sets. Typically in automotive gearboxes the mostly used sets are with central wheels (one sun and one crown wheel) with a single simple planet. The gearboxes with positive base ratio (with two planets) or with Ravigneaux set are relatively exceptional. Therefore we decided to start the test stand with the mostly used set with negative base ratio. The parameters of the planetary sets are mentioned in Table 1. To use the real gear sets from the automotive transmission we disassembled the sets from two identical automatic transmissions. The scheme of the stand can be seen in the following Figure.

Different solutions for different types of gear sets are elaborated in [6]. To be able to test different types of planetary sets the casings and their bearing houses are designed slightly overdimensioned. The following chapter is dedicated to description of the realized test stand.

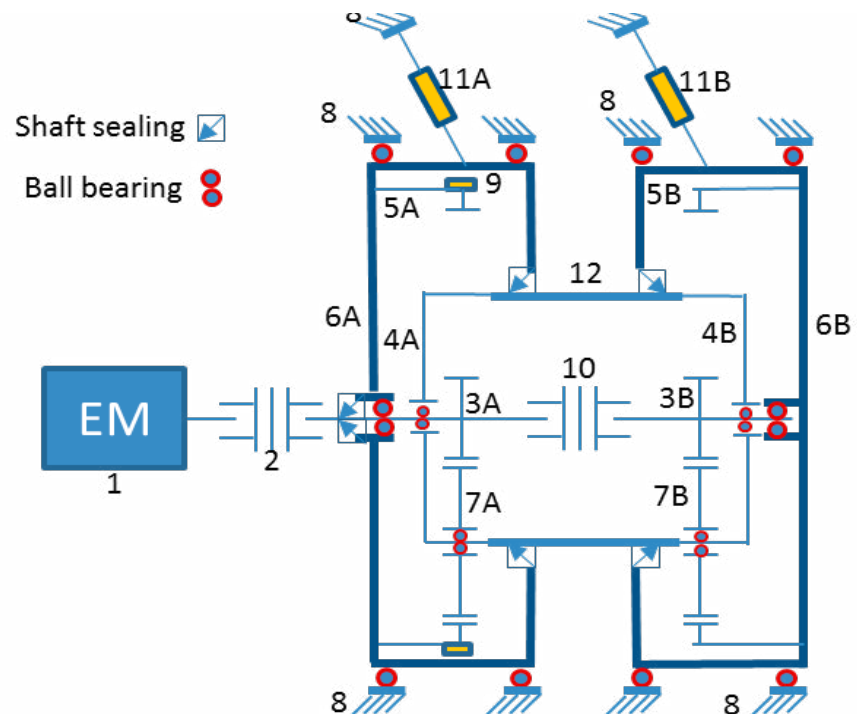

LEGEND: 1 - Electric motor, 2 - Stiff bellow clutch with clamping hub, 3 - Sun Gear, 4 -Spider, 5 - Crown wheel, 6 - Planetary set casing, 7 - Planet, 8 - Frame, 9 - Strain gauges, 10 - GE-T Coupling with flexible spider, 11 - Sensor of reactional force, 12 - Tube connecting spiders $4 A$ and $4 B, A$ - Belonging to gearbox $A, B$ - Belonging to gearbox $B$

FIGURE 1: Scheme of the new test stand for planetary gear sets OBRÁZEK 1: Schéma nového stavu pro zkoušky planetových soukolí
TABLE 1: Parameters of the tested planetary sets TABULKA 1: Parametry použitého planetového soukolí

\begin{tabular}{|lccc|}
\hline Element & Sun & Planet & Ring wheel \\
\hline Number of teeths & 31 & 22 & 74 \\
\hline Base ratio & & $\mathrm{i}^{\mathrm{r}}=-2,3871$ & \\
\hline
\end{tabular}

There are two possibilities how to introduce the preload into the circuit:

- Preload of reactional member (in Figure 1 it can be realized by preloading of one of the crown wheels. The torque can be changed any time.

- Distortion of shaft linking suns or spiders (in Figure 1 for example coupling 10 could be exchanged by bracing flange, when mounted externally from sets). The torque can be changed in steady state only.

With regard to the simplicity of the solution and with regard to the possibility of change the load any time we decided to use the first option of preload.

\section{REALISED TEST STAND}

The tested planetary sets are depicted in Figure 2. The four speed gearbox, from which we took the PGS consisted of two nested planetary sets with common sun; therefore the sun gearwheel is wide. The gear of the sun is manufactured directly on the hollow shaft, which is on one extremity equipped with splines. The crown wheel is a thin ring, which will be later equipped with strain gauges for measurement of non-uniformity of planet loading. The crown wheel is rigidly connected to a splined flange and with respect to the sun is connected via ball bearing. The spider holds three uniformly distributed planets. The spider is welded part. Between spider and sun is placed a ball bearing. For the connection of spider with the spider of the second planetary set are dedicated 6 dogs.

Every planetary set is enclosed in the circular casing, which is mounted on two ball bearings. The casing has to be mounted free in rotation, to give the possibility to measure the reactional force on the casings, i.e. the reactional force on the crown wheel. Next reason is that the preload into the circuit is introduced via loading of one reactional element, i.e. via loading of one casing.

The spiders are linked together via rigid hollow tube. The suns are connected together via the flexible coupling. To clearly distinguish between both sets, we will introduce the following notation: the PGS linked with the electric motor is called " $\mathrm{A}$ ", the PGS where the load is introduced is called " $B$ ". In the sun gear of PGSA was pressed the shaft which is via bellow coupling connected to the electric motor. The electric motor rotates the whole stand and compensates for the losses. The electric motor is controlled by frequency converter; the parameters are stated in the following table. 


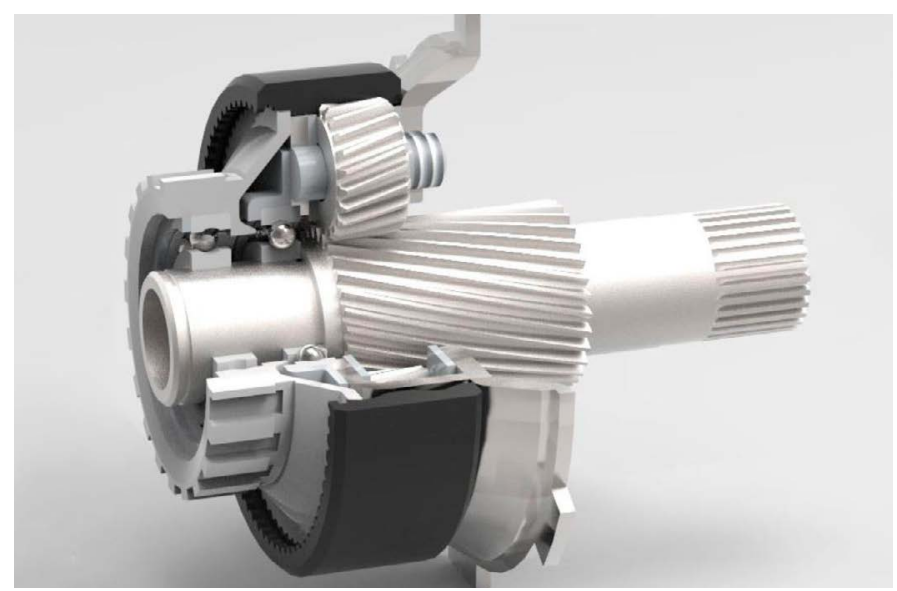

FIGURE 2A: Vizualisation of the cross section of the tested planetary gear set; [7].

OBRÁZEK 2A: Vizualizace řezu planetovým soukolím; [7].

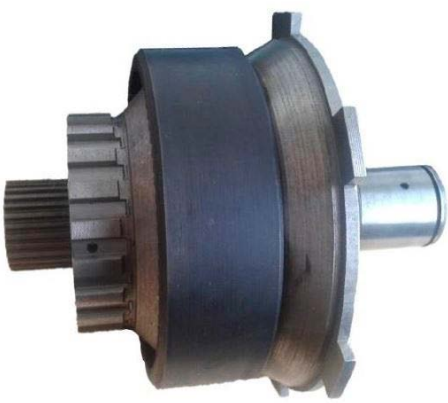

FIGURE 2B: Photo of the PGS; [7].

OBRÁZEK 2B: Fotografie planetového soukolí; [7].
TABLE 2: Parameters of electric motor TABULKA 2: Parametry elektromotoru

\begin{tabular}{|lccc}
\hline Electric motor & $\mathrm{n}_{\max }$ & $\mathrm{P}_{\max }$ & $\mathrm{M}_{\text {nominal }}$ \\
\hline ABB M3EB 100E6 & $64001 / \mathrm{min}$ & $18 \mathrm{~kW}$ & $43 \mathrm{~N} . \mathrm{m}$
\end{tabular}

The section of the assembled closed-loop planetary stand is depicted in Figure 3. Figure 4 shows the visualization of assembled stand. From Figure 4 can be clearly seen, that one planetary casing is mounted on the linear rail in axial direction of the PGS (to facilitate the final assembly), one planetary casing is mounted on the subframe, which can be transversally manipulated to achieve perfect alignment of both planetary sets. The final grinding of both frames of planetary sets was done at once, to ensure the alignment in vertical direction.

The lubrication is proposed as churning, in the future pressure lubrication will be designed. Every casing has oil inlet and outlet connection socket, as well the draining tap. For the tested PGS's there is no sealing between sun and spider, so the oil can partly fill the tube (12) connecting the spiders.

The preload is introduced via flange (9), which is screwed to the casing (2), sealed with o-rings. The flange is equipped with dogs, in which is introduced the counter dogs of load lever. The lever can be screwed to the flange (9), on the extremity of the preload lever are put the weights. The weights can be added or removed also during rotation of the stand, so the preload can be changed. The lever was designed as one side lever, only, so the change of loading torque is not possible - see Figure 4 .

LEGEND:

1 - casing of PGS "A" linked with electric motor

2 - casing of the PGS " $B$ "

3 - housing of ball bearing with axial fixation

4 - housing of ball bearing

$5+6$ - ball bearings supporting casings

7 - cover of spider sealing

8 - cover ensuring the axial fixation of bearing (6)

9 - flange for loading of PGS casing (2)

10 - cover with input shaft sealing

11 - input shaft

12 - tube connecting spiders

13 - flexible coupling connecting the suns

14 - spider sealing

15 - input shaft sealing

16 - circlip.

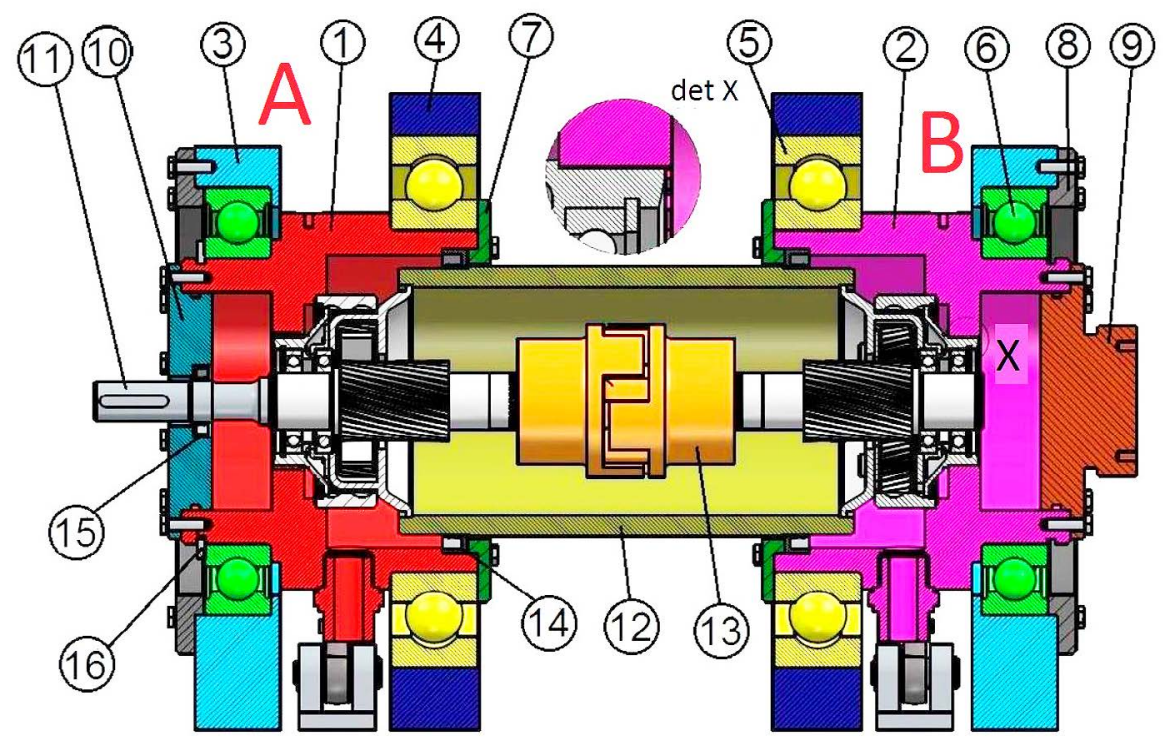

FIGURE 3: Section of assembled stand; [7]. The frames and sub-frames are not depicted.

OBRÁZEK 3: Řez sestaveným zkušebním stavem; [7]. Rámy a pomocné rámy nejsou znázorněny. 


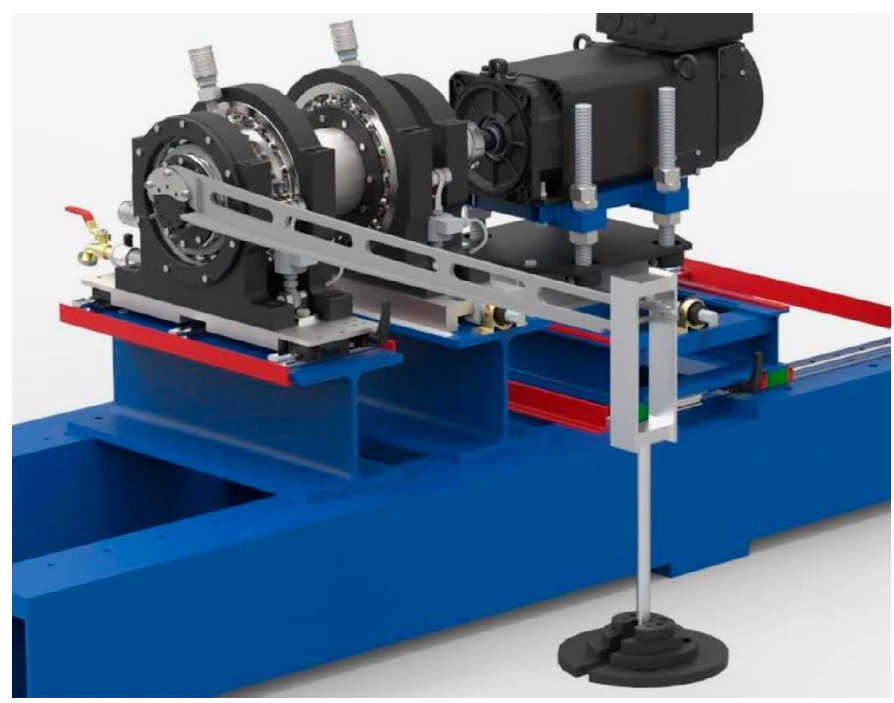

FIGURE 4: Visualization of the assembled test stand; [7]. OBRÁZEK 4: Vizualizace sestaveného zkušebního stavu; [7].

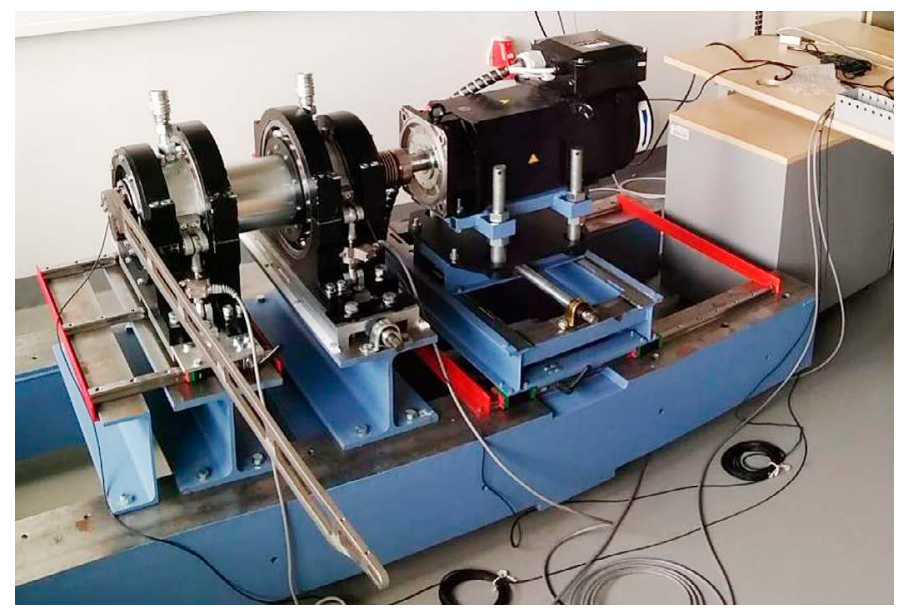

FIGURE 5:. Photo of the assembled test stand

OBRÁZEK 5: Fotografie dokončeného zkušebního stanoviště.

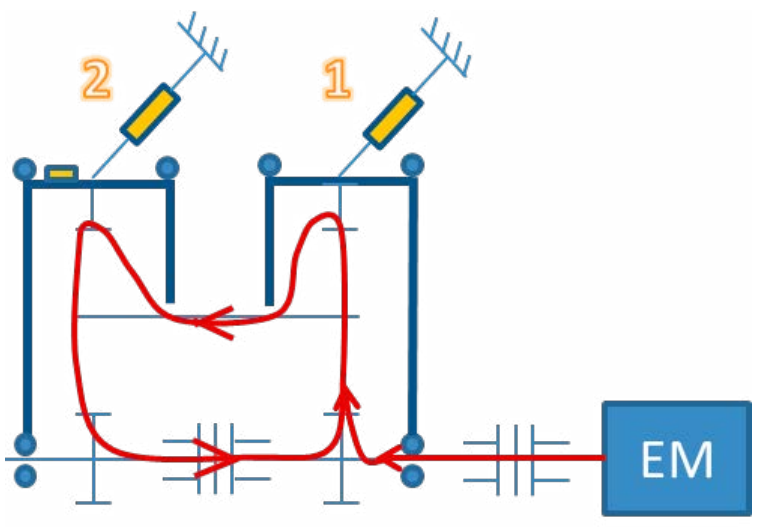

Case A) Power on Sun1 is positive.
The reactional force is sensed with help of full-bridge strain gauge sensor HBM U2A with capacity of $1 \mathrm{t}$. The sensors are capable to measure the tensile and pressure force. Above the PGS bearings, on the casing are screwed the accelerometers KS77C 10. The information about speed of rotation is actually taken from the frequency converter. Since all elements are connected via gearwheels, the speed of rotation of remaining elements can be easily calculated.

The frame holding the electric motor is composed from several sub-frames. The sub-frame is mounted on linear rails to achieve easy movement horizontally in axial direction of electric motor. To facilitate the alignment with gearbox input shaft the sub-frame is equipped with positioning screw, which can tune the position in transversal direction. The smallest part of the sub-frame where the electric motor is screwed is mounted on four screws which ensure the position in vertical direction. As the stand is designed as modular - allowing the test of the fixed axes gearwheels as well as of the planetary sets, the easy and precise tuning of position of electric motor is important. For connection of electric motor with gearbox input shaft is used bellow coupling with clamping hubs.

\section{POWERFLOW IN PLANETARY CLOSED LOOP TEST STAND}

For planetary sets are in fact just two possibilities of the powerflow in the closed loop test stand, see Figure 6 . The sense of circulating power depends on:

- The sense of the preload;

- Basic ratio of the PGS, and architecture of the tested PGS's;

- Sense of rotation and torque of the electric motor.

The determination of the magnitude of circulating power (torque) is more complex than in the case of closed-loop test stands for gearwheels (gearboxes) with fixed axes, where the preload is in fact the circulating torque; [8]. In case of planetary

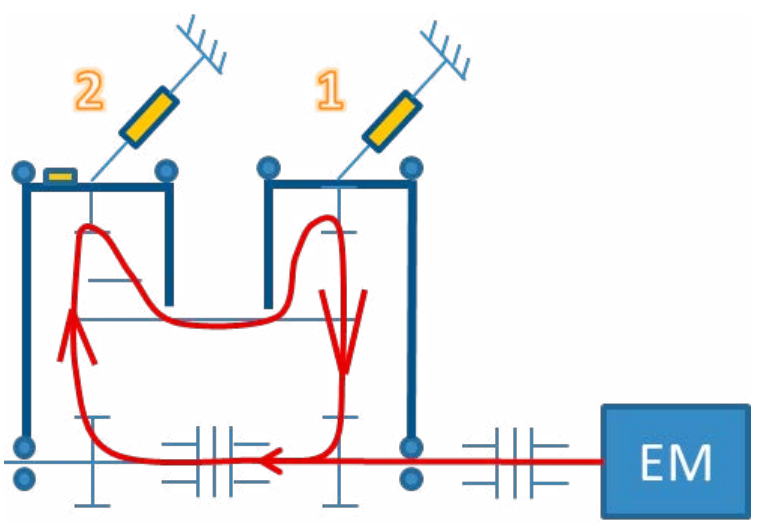

Case B) Power on Sun 2 is positive.

FIGURE 6: Two possible senses of the circulating power in the closed-loop test stand.

OBRÁzEK 6: Dva možné toky výkonu v uzavřeném zkušebním stavu 


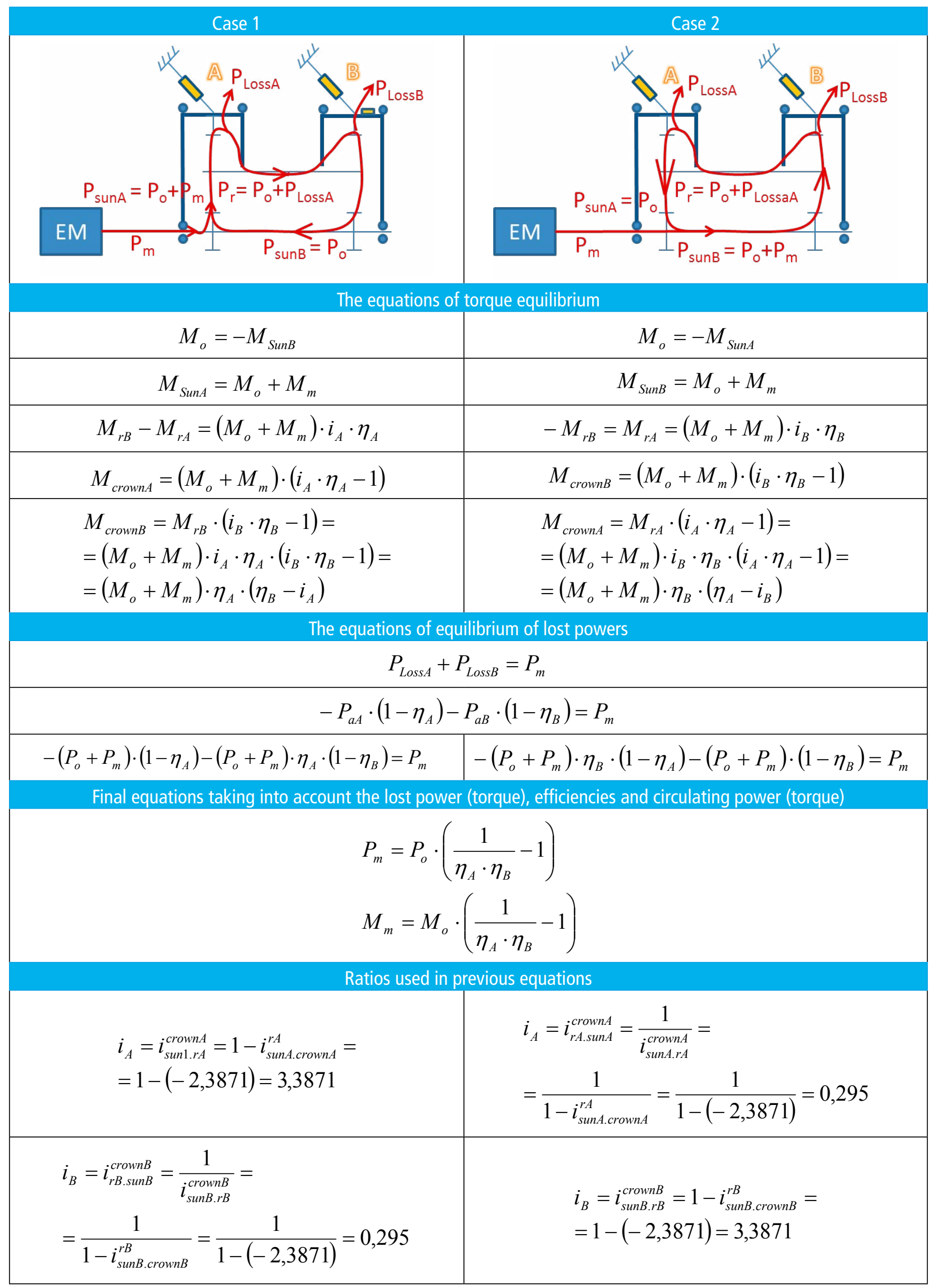


sets the preload is moment exerted on the reactional element. Firstly we will determine the powerflow and circulating power for both possible senses and then we will determine which case is relevant for our test stand.

\subsection{POWERFLOW AND CIRCULATING POWER - GENERAL DERIVATION}

To determine the magnitude of circulating power as well as the efficiency of planetary sets, we will write the equations of power and torque equilibrium. In the following Table can be seen the magnitude of powers on different elements. The appropriate equations are derived for both cases.

Before we will determine the equations valid for actual example, we will recall the definition of the lost power of any mechanism. The lost power can be determined with help of power on the input shaft, or of the output shaft.

$P_{\text {Loss }}=-P_{a} \cdot \zeta=\frac{P_{n}}{\eta} \cdot \zeta$

$\eta=1-\zeta$

We are measuring the total lost power, i.e. the power of electric motor, and the reactional moments, therefore it will be wise to carefully look on the equations of power and torque equilibrium.

\subsection{POWERFLOW IN TREATED CASE}

To determine the powerflow and magnitude of circulating power in our example, we will first treat the rotational speed, torque and power as algebraic values. We assume that the positive rotational speed and positive torque correspond with the sense of rotation and sense of torque of the electric motor. In such case the power of electric motor is also positive.

To determine the sense of circulating power, we have to first determine the sense of preload on the reactional element. We can simplify the calculation with neglecting the losses. We introduce the preload on PGS " $B$ ". The preload is introduced in the same sense as is the rotation and torque of electric motor. From the following calculation can be seen that the positive reactional torque can be obtained in Case 2 in Table 3 only.

$M_{\text {preload }}>0$

$i_{B}=+3,3871$

$\overline{M_{r B}}=-i_{B}$

$\overline{M_{\text {crown } B}}=-\overline{M_{\text {sun } B}}-\overline{M_{r B}}=-1+3,3871=+2,3871$

From the equation (3) can be seen that the positive reactional torque can be obtained only in case 2 - see Table 3 .

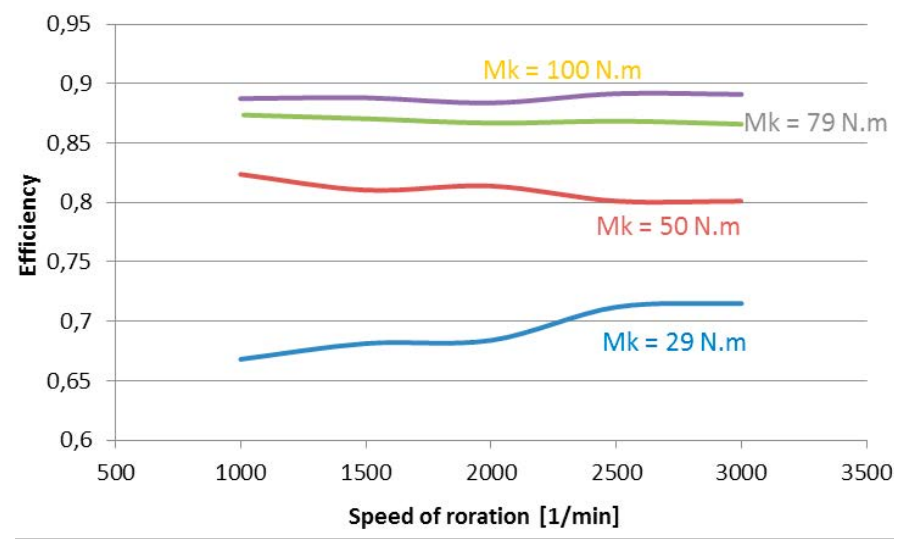

FIGURE 8: Dependence between efficiency and speed of rotation with respect to different preload on PGS $B$

OBRÁZEK 8: Závislost účinnosti na změně otáček vstupního hřídele a měnící se zátěži.

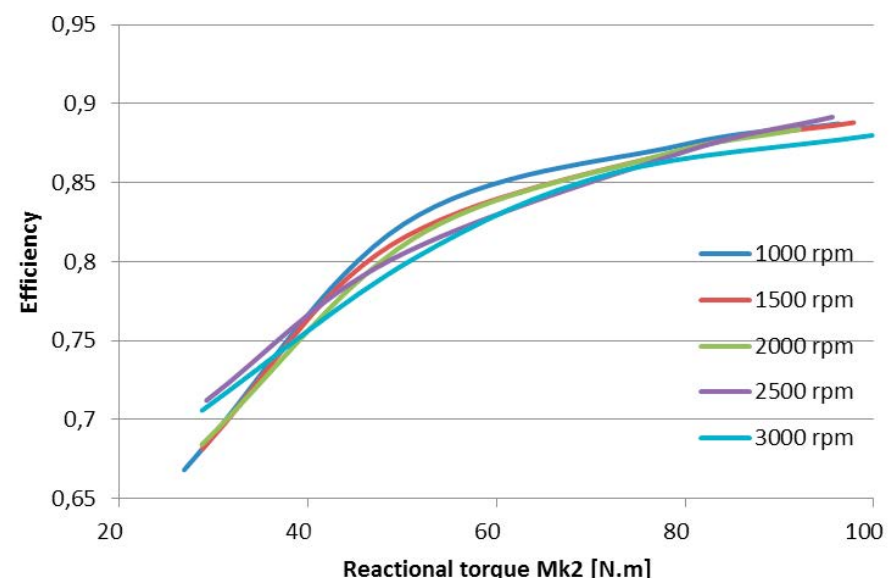

FIGURES 9: Dependence between efficiency and preload with respect to different rpm's.

OBRÁZEK 9: Závislost účinnosti na předpětí při různých otáčkách vstupu.

\section{MEASUREMENT RESULTS}

The measurement stand was recently built. Unfortunately the load cell on crown wheel "A" did not function well, so the results are from the reactional torque on crown wheel $B$ only. It means we can not determine the efficiency of the PGS " $A$ " and PGS " $B$ " separately. For planetary gear sets with high efficiency, the difference of efficiency for power flow from sun to spider with fixed crown and of the efficiency for power flow from spider to sun with fixed crown, can be neglected. In our case we obtained relatively low efficiency, but the reason is mainly in the lubrication, i.e. in the churning losses.

In the following Figure can be seen the graphs from measured data. The measurements were done with different speed of rotation and different preload. The efficiency of PGS was calculated as well as the magnitude of circulating power and torque. The measurements were done with the oil temperature equal $35 \mathrm{C}$. 
TABLE 4: Example of measured and calculated data.

TABULKA 4: Ukázka naměřených a vypočtených dat.

\begin{tabular}{ccccccc}
$\begin{array}{c}\mathrm{n} \\
{[\mathrm{rpm}]}\end{array}$ & $\begin{array}{c}\text { P_m } \\
{[\mathrm{W}]}\end{array}$ & $\begin{array}{c}\text { Mk2 } \\
{[\mathrm{N} . \mathrm{m}]}\end{array}$ & $\begin{array}{c}\text { M_m } \\
{[\text { N.m] }}\end{array}$ & Efficiency & $\begin{array}{c}\text { Mo } \\
{[\text { N.m] }}\end{array}$ & $\begin{array}{c}\text { Po } \\
{[\mathrm{W}]}\end{array}$ \\
\hline 3000 & 3104 & 99,9 & 10,2 & 0,891 & 39,9 & 12532 \\
\hline 2500 & 2549 & 95,6 & 10,0 & 0,8916 & 37,6 & 9845 \\
\hline 2000 & 2111 & 92,1 & 10,2 & 0,8838 & 36,1 & 7561 \\
\hline 1500 & 1623 & 97,9 & 10,5 & 0,8881 & 38,453 & 6038 \\
\hline 1000 & 1072 & 96,3 & 10,3 & 0,8874 & 37,8 & 3956 \\
\hline
\end{tabular}

From Figure 8 can be seen, that the efficiency is strongly dependent on the transmitted load. For low transmitted torque the efficiency is very low, while in the proportion "Load : No Load" losses is low. It means the no load losses (i.e. the lubrication, sealing) play the majority. From the graphs can be clearly seen, that for precise measurement of influence of different design changes on efficiency of planetary sets, it will be necessary to change the lubrication system.

On Figure 9 we can observe slight decrease of efficiency with increase of speed of rotation. This influence can be again explained with splash lubrication.

To get an idea how big is the circulating torque/power with respect to the preload, following table brings the overview of measured and calculated data. The chosen example shows the data for maximal loading torque.

\section{CONCLUSION}

In the previous chapter the first measurement results were presented. When changing the splash lubrication with the pressure lubrication we can in the future obtain more precise data of the efficiency of the PGS. In the future is planned to measure:

- Influence of different bearing types of planets on efficiency, magnitude of axial force acting on planets.

- Influence of radial clearance of planets and number of planets on efficiency.

- Non-uniformity of load distribution on planets.

- Endurance test.

Although not all results are presented in the paper, the concept of the test stand is approved. The test stand is cheap, simple, easy to manipulate, with big potential for future measurements.

\section{LIST OF SYMBOLS}

\section{Unknowns}

P Power

M Torque

$\mathrm{n} \quad$ Speed of rotation

i Ratio

$\varsigma \quad$ Coefficient of losses

$\eta \quad$ Efficiency

Subscripts

o Circulation (power, torque)

a Input

n Output

$\mathrm{m} \quad$ Electric motor

1 Belonging to PGS 1

2 Belonging to PGS 2

r Spider

\section{REFERENCES}

[1] Lechner G., Naunheimer H.: Automotive transmissions, Springer Verlag, 1999, ISBN 3-540-65903X

[2] Achtenova, G. and Milacek, O., "Innovative Configuration of the Closed-Loop Test Stand," SAE Technical Paper 2015-01-1092, 2015, doi:10.4271/2015-01-1092.

[3] Radev S., Einfluss von Flankenkorrekturen auf das Anregungsverhalten gerade - und Schrägverzahnter Stirnradpaarungen. Doktorarbeit TU München. 2007.

[4] http://www.strama-mps.de/produkte/pruefstaende/ standards/fzg-zahnrad-verspannungspruefstand/

[5] Šalamoun Č.: The closed loop stand for planetary gearbox testing, In: Proc. of Mechanismen und Getriebe spanabhebender Werkzeugmaschinen, 1961 (in German)

[6] Rok J.: Design of planetary gear box for closed-loop test stand. Diploma work DP2012-MV05. CTU in Prague. 2012. (in Czech)

[7] Kazda L.: Proposal of the closed loop test stand. Diploma work. CTU in Prague. 2017. (in Czech)

[8] Moravec V., Havlík J., Folta Z., Achtenová G.: Analysis of Power Flow in Closed Loop Stands for Endurance tests of Gears and Transmissions, Journal MECCA 2/2004, ISSN 1214-0821

\section{ACKNOWLEDGEMENT}

This research has been realized using the support of The Ministry of Education, Youth and Sports program NPU I (LO), project \# L01311 Development of Vehicle Centre of Sustainable Mobility. The support is gratefully acknowledged. 